\title{
Hepatic Liquoric Cyst as a Complication of Ventriculoperitoneal Shunt Insertion: A Case Report
}

\author{
Lívio Pereira de Macêdo ${ }^{1}$ Arlindo Ugulino Netto ${ }^{1}$ Kauê Franke ${ }^{1}$ Pierre Vansant Oliveira Eugenio ${ }^{2}$ \\ Lucas Ribeiro de Moraes Freitas ${ }^{20}$ Davi Coutinho Marcelino Guerra Leone20 \\ Diego Pereira de Melo Oliveira ${ }^{3}$ Eduardo Vieira de Carvalho Júnior ${ }^{1}$ Igor Vilela Faquini ${ }^{10}$ \\ Nivaldo S. Almeida ${ }^{1}$ Hildo Rocha Cirne Azevedo-Filho ${ }^{10}$ \\ ${ }^{1}$ Department of Neurosurgery, Hospital da Restauração, Recife, PE, \\ Brazil \\ ${ }^{2}$ Centro de Ciências Médicas, Universidade Federal da Paraíba, João \\ Pessoa, PB, Brazil \\ Address for correspondence Lívio Pereira de Macêdo, MD, \\ Departamento de Neurocirurgia, Hospital da Restauração, Rua João \\ Fernandes Vieira, 544, Boa Vista, Recife, PE 50050-200, Brasil \\ (e-mail: livio21@gmail.com).
}

${ }^{3}$ Faculdade de Ciências Médicas da Paraíba, João Pessoa, PB, Brazil

Arq Bras Neurocir 2021;40(4):e408-e411.

\author{
Abstract \\ Keywords \\ - ventriculoperitoneal \\ shunt \\ - cerebrospinal fluid \\ pseudocyst \\ - hepatic cyst
}

Background The ventriculoperitoneal shunt (VPS) procedure is still the most used technique for management of hydrocephalus. This article reports a case of hepatic cerebrospinal fluid (CSF) pseudocyst as a rare, but important, complication of the VPS insertion.

Case Description An 18-year-old male presented to the hospital complaining of temporal headache and visual turbidity for approximately 3 months with a history of VPS insertion for treatment of hydrocephalus and revision of the valve in adolescence. The diagnosis was based on abdominal imaging, demonstrating an extra-axial hepatic CSF pseudocyst free from infection. Following the diagnosis, the management of the case consisted in the removal and repositioning of the catheter on the opposite site of the peritoneum.

Conclusion The hepatic CSF pseudocyst is an infrequent complication of VPS procedure, but it needs to be considered when performing the first evaluation of the patient. Several techniques are considered efficient for the management of this condition, the choice must be made based on the variables of each individual case.

Introdução O procedimento de derivação ventriculoperitoneal (DVP) ainda é a técnica mais utilizada para o tratamento da hidrocefalia. Este artigo relata um caso de pseudocisto de líquido cefalorraquidiano (LCR) hepático como uma complicação rara, mas importante, da inserção do shunt ventriculoperitoneal (VP).

Descrição do Caso Um homem de 18 anos deu entrada no hospital com queixa de cefaleia temporal e turvação visual há aproximadamente 3 meses, com histórico de inserção da DVP para tratamento de hidrocefalia e revisão da válvula na adolescência. $O$ diagnóstico foi baseado em exames de imagem abdominais, demonstrando um received

October 14, 2020

accepted

March 9, 2021

published online

August 30, 2021
DOI https://doi.org/ $10.1055 / \mathrm{s}-0041-1732441$. ISSN 0103-5355.

\footnotetext{
c) 2021. Sociedade Brasileira de Neurocirurgia. All rights reserved. This is an open access article published by Thieme under the terms of the Creative Commons Attribution-NonDerivative-NonCommercial-License, permitting copying and reproduction so long as the original work is given appropriate credit. Contents may not be used for commercial purposes, or adapted, remixed, transformed or built upon. (https://creativecommons.org/ licenses/by-nc-nd/4.0/) Thieme Revinter Publicações Ltda., Rua do Matoso 170, Rio de Janeiro, RJ, CEP 20270-135, Brazil
} 
pseudocisto hepático extraaxial de LCR, livre de infecção. Após o diagnóstico, o manejo do paciente se baseou na retirada e reposicionamento do cateter no sítio oposto do peritônio.

Conclusão O pseudocisto hepático de LCR é uma complicação infrequente do procedimento de DVP, mas deve ser considerado na primeira avaliação do paciente. Diversas técnicas são consideradas eficientes para o manejo desta condição, a escolha deve ser feita com base nas variáveis de cada caso individual.

\section{Introduction}

Ventriculoperitoneal (VP) shunt remains the most used technique for the treatment of hydrocephalus. ${ }^{1}$ With the increased survival of patients undergoing the procedure, we can identify some complications, such as abdominal cysts of cerebrospinal fluid (CSF). These are rare complications of VP shunt, accounting for only $0.25 \%$ of all cases with abdominal disorders. $^{2,3}$

This article aims to report a case of hepatic CSF pseudocyst, an even more unusual example of abdominal complications after a VPS procedure, in which there was perforation of a massive organ. The literature review performed was based on PubMed, using the keywords and Boolean operators VP shunt complications OR ventriculoperitoneal shunt AND hepatic pseudocyst OR CSF pseudocyst OR intrahepatic cyst, restricting the search to articles in the English language. No other limitations were included, and less than 50 cases reporting this condition in the past 20 years were found.

\section{Case Report}

TJC, male, 18 years old, with VPS since childhood due to hydrocephalus of idiopathic etiology, with history of revision of the valve in adolescence, presented to the neurology service of Hospital da Restauração, in Recife, Brazil, in August 2020. The patient complained of severe temporal headache associated with visual turbidity for approximately 3 months. He brought a recent brain computed tomography (CT) scan with no abnormalities. Despite this, the examination of the eye fundus already showed papilledema, with visual acuity of 20/20 bilaterally.

In a detailed investigation, it was evidenced that the patient had visual turbidity associated with abdominal pain. Therefore, a new brain CT scan without contrast was requested, which did not show lesions or signs of hydrocephalus and, additionally, a brain magnetic resonance imaging (MRI) was performed, which showed no signs of aqueduct stenosis (-Fig. 1). For better investigation, the patient underwent abdominal CT and evaluation by the ophthalmology and general surgery teams. On the abdominal CT scan, the presence of an intrahepatic abdominal catheter was observed, forming a hepatic pseudocyst of intracapsular CSF, due to the probable entry of the distal VPS catheter through the hepatic capsule (-Fig. 2 ).

The surgical management of the patient was performed with removal of the catheter from the liver capsule and repositioning of the catheter, intraperitoneally, in another site at the same surgical time, due to the absence of signs of infection in surgery. Venous antibiotic therapy (vancomycin and ceftriaxone) was performed for 14 days. The patient evolved with stability and a positive prognosis. Control abdominal CT was performed 8 days after the surgery, showing resorption of more than $70 \%$ of the hepatic cyst without need for further interventions (-Fig. 3). The patient stayed in the hospital for 20 days, and was dismissed without any complications.

\section{Discussion}

The set of abdominal cysts are a well-recognized but uncommon complications of the VPS procedure. ${ }^{4}$ However, the hepatic CSF pseudocyst is an even less frequent condition classified into intraaxial or extraaxial cases. Intraaxial cysts happen when the tip of the shunt is lodged in the liver and causes the cyst to grow within the organ parenchyma. ${ }^{5}$ Similar to the case reported, extraaxial cysts develop when there is a migration of the distal catheter through the Glisson capsule, resulting in the subcapsular accumulation of CSF. ${ }^{6}$ In addition, a case report described a cyst whose smaller part

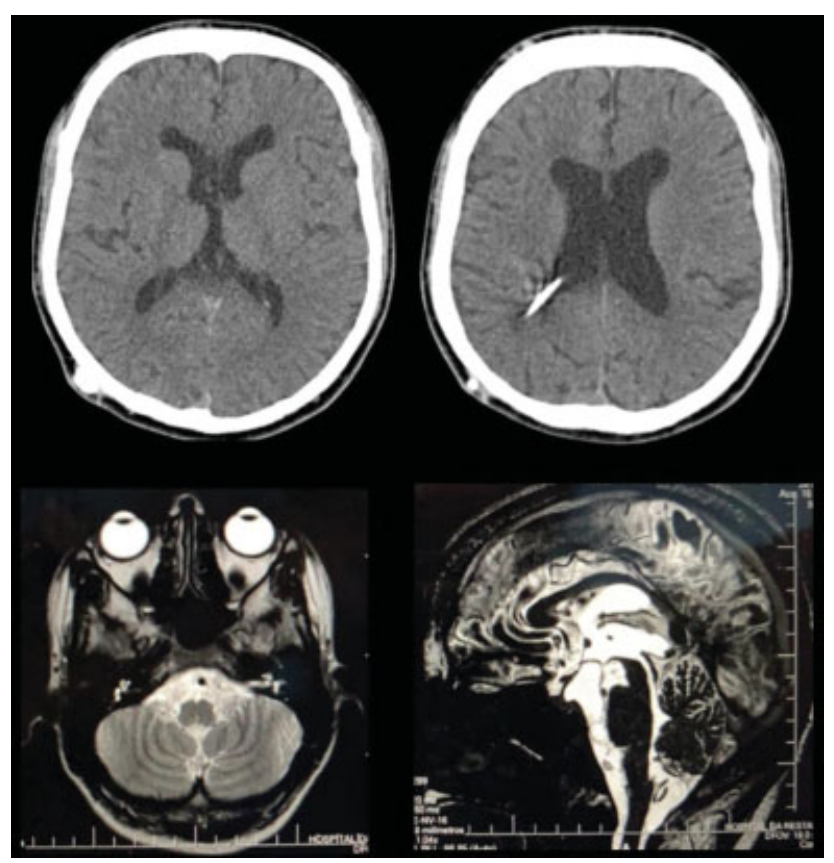

Fig. 1 Brain computed tomography scan without contrast showing no lesions or signs of hydrocephalus (upper). Brain magnetic resonance imaging showing no fossa posterior. 


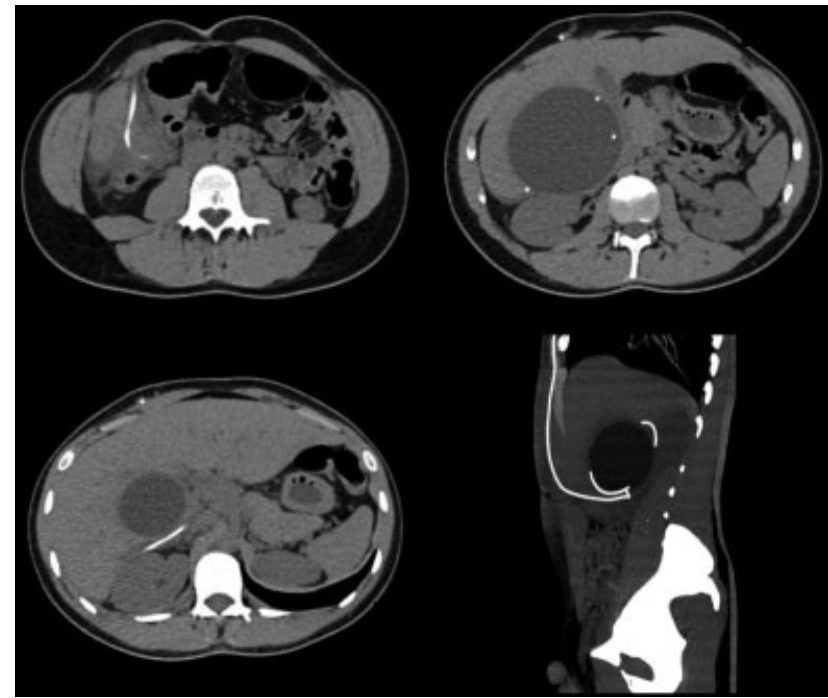

Fig. 2 Abdominal computed tomography scan showing an hepatic pseudocyst of intracapsular cerebrospinal fluid, due to the probable entry of the distal ventriculoperitoneal shutn catheter through the hepatic capsule

was inside the parenchyma and the largest part outside, configuring a case of juxtahepatic CSF cyst. ${ }^{7}$

There are several etiologies for the development of hepatic CSF pseudocysts. Among the possible etiologies, sterile or infected inflammatory processes, such as peritonitis, reactions against foreign bodies, and irritation of the peritoneum due to continuous exposure to $\mathrm{CSF}^{8}$ were considered the most common phenomena that could cause this condition by destabilizing the capsular structure of the liver. ${ }^{9}$ Furthermore, intraperitoneal fibrosis has a great role in the perforation process as it promotes the fixation of the tip of the distal catheter and the continued mechanical irritation of the organ's periphery. Among other causes, multiple revisions of the shunt in the abdomen as well as prior surgeries in that location, CSF malabsorption, and history of intracranial tumor are factors that predispose the formation of abdominal and hepatic pseudocysts. ${ }^{10,11}$

Image findings are essential for the diagnosis of this condition. Ultrasound examination, because it is simple, economical, and provides satisfactory diagnosis results, is the most advisable method for the first evaluation in most cases. In contrast, abdominal CT ensures an accurate diagnosis, especially when the CSF cyst grows to the point of deforming the normal internal configuration of the abdomen ${ }^{12,13}$ or its growth is extraaxial, in which the liver tissue cannot be identified in the periphery of the cyst. With the CT exam, it is possible to make differential diagnoses of conditions that mimic the hepatic CSF pseudocyst symptoms (to exemplify, appendicitis, diverticulitis, volvulos, among others). Finally, it is emphasized that the efficient interpretation of the neurological deficits presented by the patient is indispensable.

Various types of treatment approaches have been reported in the analyzed literature; however, only one case has experienced recurrence. ${ }^{8}$ Due to the scarcity of cases and the fact that the treatment depends on the patient's particular characteristics as well as on the surgeon's experience and

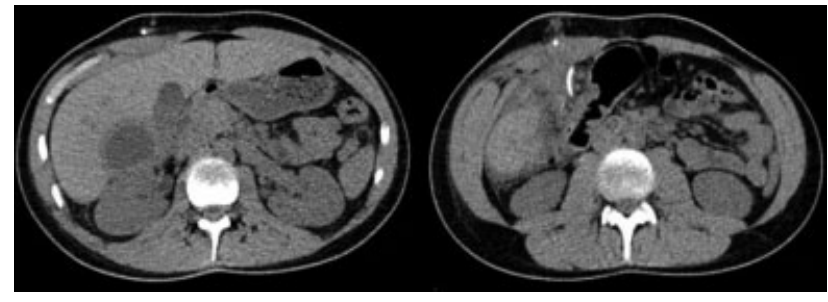

Fig. 3 Control abdominal computed tomography scan showing resorption of more than $70 \%$ of the hepatic cyst

findings during the procedure, there is no consensus in the treatment of the hepatic CSF pseudocyst. After the possible infection is treated, ${ }^{14}$ the most common procedures include 6 main categories (1) removal of the primary shunt, placement of external ventricular shunt (EVD) followed by VP shunt insertion ${ }^{15,16}$; (2) removal of the primary shunt, placement of the EVD, followed by the insertion of a ventriculoatrial shunt (VAS) ${ }^{17,18}$; (3) removal of the primary shunt and conversion to VAS $^{19}$; (4) repositioning of the distal catheter to the opposite side of the peritoneum ${ }^{18,20}$; (5) exploratory laparotomy, removal of the primary shunt, EVD followed by VAS or VPS ${ }^{17,21}$; (6) other treatment modalities, such as aspiration, paracentesis or excision of the pseudocyst. $^{22-24}$ In the case demonstrated in this report, due to the absence of infection and spontaneous resorption of $>70 \%$ of the CSF pseudocyst, the management was repositioning the distal catheter on the opposite site of the peritoneum.

\section{Conclusion}

The present case report describes a rare complication of the VPS technique. Hepatic CSF pseudocysts should be suspected in patients with a history of surgery for shunt placement for hydrocephalus treatment, and the diagnostic approach should be based on ultrasound and abdominal CT scans. In the reported case, after confirming the absence of infection and the natural resorption of the cyst, the surgical procedure chosen was to reposition the catheter on the opposite side of the peritoneum.

Conflict of Interests

The authors report no conflict of interests.

\section{References}

1 Limbrick DD Jr, Baird LC, Klimo P Jr, Riva-Cambrin J, Flannery AMPediatric Hydrocephalus Systematic Review and EvidenceBased Guidelines Task Force. Pediatric hydrocephalus: systematic literature review and evidence-based guidelines. Part 4: Cerebrospinal fluid shunt or endoscopic third ventriculostomy for the treatment of hydrocephalus in children. J Neurosurg Pediatr 2014;14(Suppl 1):30-34. Doi: 10.3171/2014.7.PEDS14324

2 Lortat-Jacob S, Pierre-Kahn A, Renier D, Hirsch JF, Martelli H, Pellerin D. [Abdominal complications of ventriculo-peritoneal shunts in children. 65 cases]. Chir Pediatr 1984;25(01):17-21

3 Dabdoub CB, Fontoura EA, Santos EA, Romero PC, Diniz CA. Hepatic cerebrospinal fluid pseudocyst: A rare complication of ventriculoperitoneal shunt. Surg Neurol Int 2013;4:162 
4 Anderson CM, Sorrells DL, Kerby JD. Intraabdominal pseudocysts as a complication of ventriculoperitoneal shunts. J Am Coll Surg 2003;196(02):297-300

5 Chitkara N, Gupta R, Singla SL, Sharma NK. Lower end of ventriculoperitoneal shunt embedding in liver parenchyma. Neurol India 2004;52(03):405

6 Wang F, Miller JH. Cerebrospinal fluid pseudocyst presenting as a hepatic mass: a complication of ventriculoperitoneal shunt. Pediatr Radiol 1989;19(05):326-327

7 Verma A, Mohan S, Gupta A. Ventriculo-peritoneal shunts can cause liver injury, juxta and intrahepatic pseudocysts: imaging findings and review of literature. Clin Neurol Neurosurg 2012;114 (04):389-391

8 Berkmann S, Schreiber V, Khamis A. Recurrent intrahepatic dislocation of ventriculoperitoneal shunt. Minim Invasive Neurosurg 2011;54(02):83-86

9 de Aquino HB, Carelli EF, Borges Neto AG, Pereira CU. Nonfunctional abdominal complications of the distal catheter on the treatment of hydrocephalus: an inflammatory hypothesis? Experience with six cases. Childs Nerv Syst 2006;22(10): 1225-1230

10 Mobley LW III, Doran SE, Hellbusch LC. Abdominal pseudocyst: predisposing factors and treatment algorithm. Pediatr Neurosurg 2005;41(02):77-83. Doi: 10.1159/000085160

11 Kaplan M, Ozel SK, Akgun B, Kazez A, Kaplan S. Hepatic pseudocyst as a result of ventriculoperitoneal shunts: case report and review of the literature. Pediatr Neurosurg 2007;43(06):501-503

12 Faraj W, Ahmad HH, Mukherji D, Khalife M. Hepatic cerebrospinal fluid pseudocyst mimicking hydatid liver disease: a case report. J Med Case Reports 2011;5:475

13 Hsieh CT, Pai CC, Tsai TH, Chiang YH, Su YH. Hepatic cerebrospinal fluid pseudocyst: a case report and review of the literature. Neurol India 2006;54(01):86-88
14 Arsanious D, Sribnick E. Intrahepatic Cerebrospinal Fluid Pseudocyst: A Case Report and Systematic Review. World Neurosurg 2019;125:111-116. Doi: 10.1016/j.wneu.2019.01.150

15 Fischer EG, Shillito J Jr. Large abdominal cysts: a complication of peritoneal shunts. Report of three cases. J Neurosurg 1969;31 (04):441-444

16 Gaskill SJ, Marlin AE. Pseudocysts of the abdomen associated with ventriculoperitoneal shunts: a report of twelve cases and a review of the literature. Pediatr Neurosci 1989;15(01):23-26, discussion 26-27

17 Gutierrez FA, Raimondi AJ. Peritoneal cysts: a complication of ventriculoperitoneal shunts. Surgery 1976;79(02):188-192

18 Hahn YS, Engelhard H, McLone DG. Abdominal CSF pseudocyst. Clinical features and surgical management. Pediatr Neurosci1985-198612(02):75-79

19 Burchianti M, Cantini R. Peritoneal cerebrospinal fluid pseudocysts: a complication of ventriculoperitoneal shunts. Childs Nerv Syst 1988;4(05):286-290. Doi: 10.1007/BF00271925

20 Egelhoff J, Babcock DS, McLaurin R. Cerebrospinal fluid pseudocysts: sonographic appearance and clinical management. Pediatr Neurosci1985-198612(02):80-86. Doi: 10.1159/000120224

21 Grosfeld JL, Cooney DR, Smith J, Campbell RL. Intra-abdominal complications following ventriculoperitoneal shunt procedures. Pediatrics 1974;54(06):791-796

22 Davidson RI, Lingley JF. Intraperitoneal pseudocyst: treatment by aspiration. Surg Neurol 1975;4(01):33-36

23 Gebarski KS, Gebarski SS, McGillicuddy JE. Cerebrospinal fluid abdominal cyst. Computed tomographic resolution of a sonographic dilemma. Surg Neurol 1984;21(04):414-416. Doi: 10.1016/0090-3019(84)90123-x

24 Norfray JF, Henry HM, Givens JD, Sparberg MS. Abdominal complications from peritoneal shunts. Gastroenterology 1979;77 (02):337-340 